\title{
技術報告 TECHNICAL REPORT
}

\section{M スターコンテナを用いたアカマツ緑化苗生産の試み}

\section{米道 学*・軽込 勉・塚越剛史・久本洋子・楠本 大}

東京大学大学院農学生命科学研究科附属演習林千葉演習林

摘要 : 近年, 林業種苗の苗木生産手法の一つとしてマルチキャビ ティコンテナを使用した苗木生産法がある。コンテナによる苗木 生産は露地による苗木生産に比べ伸長成長がよく，短期間の育苗 で植栽が可能になると注目を浴びている。そのため, 緑化用の苗 木生産においてもコンテナを用いることは有効であると予想され る。しかし，実際に緑化用苗木生産を目的とした報告は数少ない。 そこで本稿では，アカマツ緑化用苗木の生産方法として，M ス ターコンテナの有用性を検討するため, 苗の成長を露地苗と比較 した。また, 労働力の低減効果をみるため除草にかかる時間を調 査した。その結果, 播種から 2 年で平均苗高約 $50 \mathrm{~cm}$ (形状比 53) に達し, 露地よりも 1 年早く植栽可能な大きさにすることができ た。また, コンテナを使用することで除草作業が 2 年間で 30 分 となり, 労働時間の削減にも効果が認められた。

キーワード : 省力化, 生存率, 抵抗性アカマツ, 根元直径, 苗高

\section{1.はじめに}

林業種苗生産において, 低コスト再造林手法としてコンテ ナ苗が注目をあびている。一般にコンテナ苗とは, マルチ キャビティコンテナにより生産した苗木のことを指し，コン テナの栽培孔にリブやスリットを設けることで根巻きを抑制 し，底面を開放することで根の成長が止まり，根切りの必要 がなくなる。さらに，コンテナを使用することで育苗期間を 短縮することができると報告されている ${ }^{1,5,7)}$ 。

これらのメリットは緑化用の苗木生産においても有用であ ると予想される。しかし，これまで報告されてきたコンテナ による苗木生産技術は主に林業用を前提としており，苗高 $30 \mathrm{~cm}$ 程度の苗木生産を目標としている。一方, 緑化用苗で は「公共用緑化樹木等の品質寸法規格基準 (案) 」3)にあるよ うに，苗高 $50 \mathrm{~cm}$ 以上が大きさの基準となっており，コン テナを利用して，より大きな苗木の生産が可能かについては 検証が必要である。本報告では，これまでコンテナ苗の生産 報告では数少ないアカマツについて, 緑化用苗の育苗に対す るコンテナの有効性を検討した。

\section{2. 材料と方法}

コンテナ苗生産は, 東京大学大学院農学生命科学研究科附 属演習林千葉演習林 (以下, 千葉演習林) 札鄉苗畑で行った。
使用したコンテナは，M スターコンテナ（Multi-Stage Adjustable Rolled Container) とした" ${ }^{4)}$ このコンテナは, ポリ シートであるアプトン（四国化工株式会社）を丸めた筒状容 器を 40 孔のニュー TO トレー $(33 \mathrm{~cm} \times 52 \mathrm{~cm})$ で支えるコ ンテナである (写真-1)。筒状容器の高さは $15 \mathrm{~cm}$ とした。 コンテナに使用した培地は, ココピートオールド（株式会社 トップ）1Lに対し緩効性肥料ハイコントロール 085 （ジェ イカムアグリ株式会社) $20 \mathrm{~g}$ と水 $0.5 \mathrm{~L}$ を混合したものを 1 容器につき $300 \mathrm{cc}$ 使用した。 2 年目からは追肥として錠剂 肥料プロミック（株式会社ハイポネックスジャパン）を 4 月は 2 錠/孔で配置し，6月以降は， 2 か月毎に 1 個/孔で配 置した。種子は, 千葉演習林で選抜されたマツ材線虫病抵抗 性アカマツ ${ }^{2.9} 4$ 系統から 2013 年に採種された種子を均等混 合したものを用いた。 2018 年 5 月に 1 容器当たり 4 粒を播 種し, 1 容器に複数の発芽が確認された場合は, 間引きして 1 本に仕立てた。容器はトレーに隙間なく配置し（1トレー 当たり 40 容器), 全部で 3 トレーを用意した。2019 年は成 長した苗木の間隔を開けるために, 容器をトレーの 1 孔お きに千鳥配置とした (1 トレー当たり 20 容器, 6 トレー) (写 真-2)。なお, トレーの配置場所は屋根の無い露天環境とな る。潅水は毎日 9 時と 16 時に 10 分間ずつ自動潅水装置を 用いて行った。

コンテナ苗と成長量や生存率を比較するため, 千葉演習林 札郷苗畑で栽培されている露地苗を対照とした。露地苗は, 2016 年 4 月にコンテナと同じマツ材線虫抵抗性アカマツ家 系を播種し， 2017 年 4 月と 2018 年 4 月に床替えを行った。 なお, 播種床には完熟牛糞堆肥を $3 \mathrm{~L} / \mathrm{m}^{2}$, 床替え床には 6

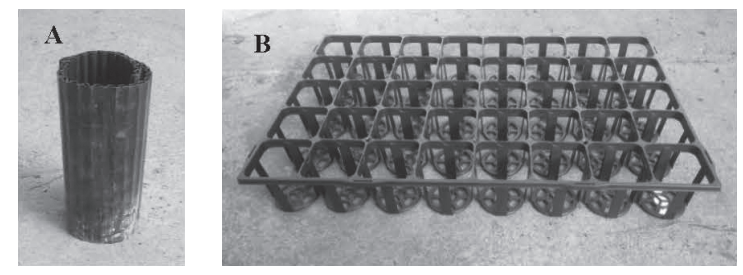

写真-1 使用した M スターコンテナ資材

A：筒状容器（アプトン） B ：筒状容器を支える 40 孔 トレー（ニューTOトレー） 


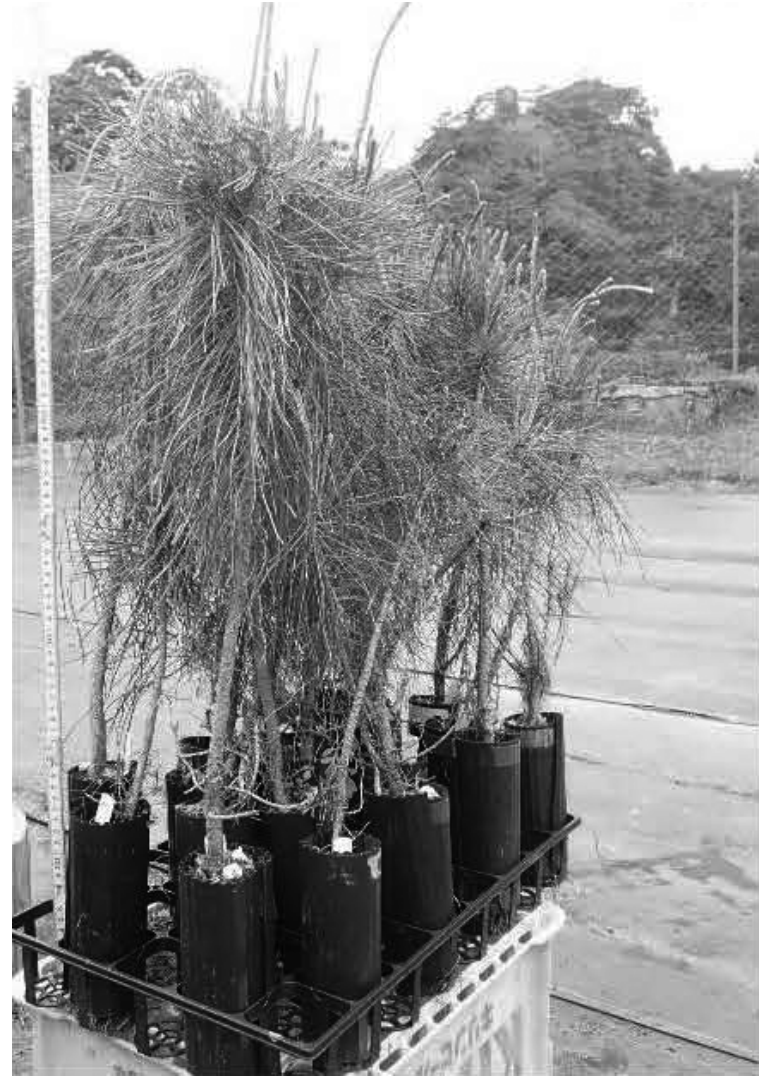

写真-2 M スターコンテナに千鳥配置したアカマッ苗 の様子（2020 年 4 月）

$\mathrm{L} / \mathrm{m}^{2}$ の割合で土䁃混和させ，植栽密度を 1 回目は 50 本/ $\mathrm{m}^{2}, 2$ 回目は 23 本 $/ \mathrm{m}^{2}$ として床替えした。潅水は自然降雨 のみとした。

コンテナ苗に対しては，2019 年 4 月（播種から 1 年後） と 2020 年 4 月（播種から 2 年後）に根元直径と苗高を測定 し, 生存率を調查した。露地苗に対しては, 多数ある中から コンテナ苗と同数の 120 本を無作為に選択し, その苗に対 して 2017 年 4 月（播種から 1 年後）, 2018 年 4 月（播種か ら 2 年後), 2019 年 4 月（播種から 3 年後）に根元直径, 苗高および生存率を調查した。

また, 2018 年 5 月に播種したコンテナ苗 120 本につい て, 2018 年と 2019 年の育苗期間中の除草を 1 人で行い, その除草作業量を作業時間で計測した。

\section{3. 結果と考察}

\section{1 苗の大きさと生存率}

「公共用緑化樹木の品質寸法規格基準 (案) $]^{3}$ によれば, 緑 化樹としてのアカマツ苗の寸法規格は最小でも樹高 $50 \mathrm{~cm}$, 幹周設定なしとなっている。コンテナ苗の播種から 1 年後 の大きさは，根元直径が $4.2 \mathrm{~mm}$ ，苗高が $16.2 \mathrm{~cm}$ となり， 露地苗の 1 年後に比べてそれぞれ約 1.7 倍, 1.5 倍大きかっ た (表-1)。また, コンテナ苗の 2 年後の根元直径と苗高は それぞれ $9.7 \mathrm{~mm}, 49.9 \mathrm{~cm}$ となり, 露地苗の 2 年後に比べ てそれぞれ 1.3 倍，1.6 倍大きかった。また，コンテナ苗の
表-1 コンテナ苗と露地苗の成長と生存率の推移

\begin{tabular}{|c|c|c|c|c|c|}
\hline 苗 種 & $\begin{array}{c}\text { 播種後の } \\
\text { 経過年数 } \\
\text { (年) }\end{array}$ & $\begin{array}{c}\text { 根元直徍 } \\
(\mathrm{mm}) \\
\text { 平均 } \pm \\
\text { 標準偏差 }\end{array}$ & $\begin{array}{c}\text { 苗高 }(\mathrm{m}) \\
\text { 平均 } \pm \\
\text { 標準偏差 }\end{array}$ & $\begin{array}{c}\text { 形状比 } \\
\text { 平均 } \pm \\
\text { 標準偏差 }\end{array}$ & $\begin{array}{c}\text { 生存率 } \\
(\%)\end{array}$ \\
\hline \multirow{2}{*}{ コンテナ } & 1 & $4.2 \pm 0.9$ & $16.2 \pm 4.0$ & $39.5 \pm 0.9$ & 100 \\
\hline & 2 & $9.7 \pm 2.6$ & $49.9 \pm 9.6$ & $53.2 \pm 1.1$ & 88 \\
\hline \multirow{3}{*}{ 露 } & 1 & $2.5 \pm 0.7$ & $10.8 \pm 2.8$ & $45.5 \pm 1.4$ & 100 \\
\hline & 2 & $7.2 \pm 1.9$ & $30.4 \pm 7.7$ & $43.7 \pm 1.2$ & 88 \\
\hline & 3 & $12.9 \pm 3.4$ & $43.4 \pm 12.0$ & $34.0 \pm 0.7$ & 86 \\
\hline
\end{tabular}
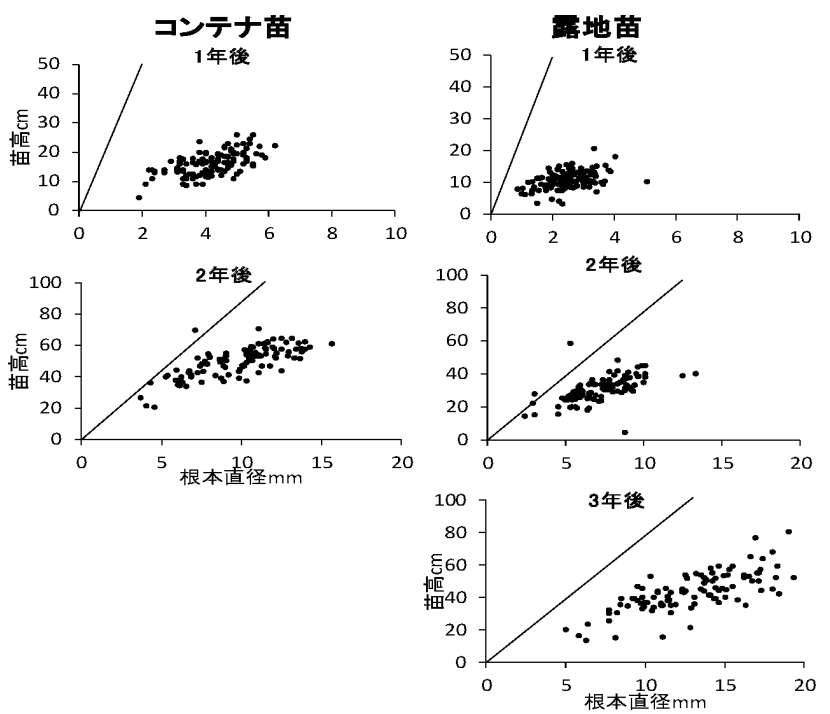

図-1 コンテナおよび露地で育苗したアカマツ苗の苗高と根 元直径の関係。

2 年後の苗高は, 露地苗の 3 年後と比べてもやや大きかった (表-1, 図-1)。このことから, コンテナ苗は露地苗に比べ て伸長成長, 肥大成長ともに優れており, 特に苗高において は露地苗よりも 1 年早く成長させることが可能であること が示された。

コンテナ苗の形状比は 1 年後が $39.5,2$ 年後が 53.2 とな り, 2 年目に徒長する傾向がみられた（表-1）。一方, 露地 苗の形状比は 1 年後が $45.5,2$ 年後が $43.7,3$ 年後が 34.0 となり, 3 年目により肥大した形状になった。スギのコンテ ナ苗では植栽後の倒伏を抑制するために形状比を 80 以下に することを推奨している ${ }^{6}$ 。形状比が 100 を超えると後年の 成長が露地苗に比べ悪くなる8)。アカマツもスギと同じよう に倒伏するとすれば，今回の試験で育てたほとんどの苗は十 分倒伏に耐えうる形状比であると考えられた（図-1）。

コンテナ苗の生存率は播種から 2 年後で $88 \%$ の生存が確 認された。一方, 露地苗の生存率は播種から 2 年後に $88 \%$, 3 年後に $86 \%$ となり, コンテナ苗の生存率とは有意な差がな かった（ $\chi^{2}$ 検定 $p>0.05 ） 。$

\section{2 除草作業}

コンテナ苗の除草に要した時間は 2018 年に 30 分のみで, 2019 年には除草作業は発生しなかった。コンテナ苗では, 
人工培土を用いることにより雑草種子の混入がなかったこ と, 植栽面積が露地苗に比べ少ないことが除草時間を軽減さ せた要因だと考えられた。なお，露地苗の除草時間は床替え 以降において 2017 年では 150 分, 2018 年では 75 分かかっ ており, コンテナ苗に比べ 7 倍程度多く費やしていた。

\section{4. まとめ}

今回の試験条件下では, コンテナ苗による苗木生産は露地 での苗木生産に比べ短い期間で苗高の高いアカマツの苗が作 出可能であることが示された。今回， 2 年後のコンテナ苗で 苗高が $50 \mathrm{~cm}$ 以上となったのは 60 本あり，半数が緑化樹と しての基準を満たすことができた。

また，コンテナ苗はコンテナや培土など資材費が嵪むもの の, 育苗期間や除草時間が短縮され，労働力の面では省力化 できる可能性がある。さらに，コンテナ苗は植付け時の労働 カやコストの削減が期待されており ${ }^{4)}$, 総合的にみても, ア カマツ苗をコンテナで栽培することのメリットは大きいと予 想された。

謝辞：本研究の一部は, (公社) ゴルフ緑化促進会のゴルフ緑 化促進会創立 40 周年記念事業による助成を受けて行われ た。東京大学大学院農学生命科学研究科附属演習林教育研究 センターの後藤晋准教授にはコンテナ苗について適切な助言 を頂いた。また育苗においては，糟谷育代氏，宮原はな氏， 吉田龍三氏，富川勲氏にご協力いただいた。ここに媣く感謝 する。

\section{引用文献}

1）荒木功介（2016）肥効期間の長い暖効性肥料を用いた追肥 をしないクロマツ 1 年生コンテナ苗の育苗方法, 関東森林 研究, 67(1): 133-136.

2）糟谷重雄・佐倉詔夫・岸 洋一（1990）マツ材線虫病抵抗 性マツの選抜育種一家系とクローンの比較一, 東京大学農 学部演習林報告, 83: 19-30.

3）国土交通省都市 - 地域整備局公園緑地 - 景観課緑地環境室 （2009）公共用緑化樹木等品質寸法規格基準（案）の解説 (第 5 次改訂対応版), 日本緑化センター, $212 \mathrm{pp}$

4）三樹陽一郎（2010）M スターコンテナを用いたスギ苗の 育成試験（I）一容器サイズが根系形成と苗木成長に与え る影響一, 九州森林研究, 63: 78-80.

5）大平峰子・松下通也（2019）施肥量がスギ実生苗に及ぼす 影響, 日本森林学会誌, 101: 109-114.

6）重永英年・山川博美・野宮治人（2014）植栽直後に倒伏し たスギコンテナ苗のその後の回復と成長，第 125 回日本森 林学会大会学術講演集, P2-052.

7）八木橋勉 - 中村克典 - 齋藤智之 - 松本和馬 -八木貴信 - 柴 田銃江・野口麻穂子・駒木貴影（2015）クロマツコンテナ 苗の当年生苗利用と通年植栽の可能性, 日本森林学会誌, 97: 257-260.

8）八木橋勉 - 中谷友樹 - 中原健一 - 那須野俊 - 櫃間 岳 - 野 口麻穂子 - 八木貴信 - 齋藤智之 · 松本和馬 $\cdot$ 山田 健 - 落 合幸仁（2016） スギコンテナ苗と裸苗の成長と形状比の関 係, 日本森林学会, 98: 139-145.

9）米道 学・鈴木祐紀・塚越剛史・里見重成・軽込 勉 - 池 田裕行 ・ 山田利博 (2008) 千葉演習林におけるマツ材線虫 病に対する選抜育種一新たな選抜と採種園産苗木の再検 定一, 関東森林研究, 59: 113-116.

$(2020$ 年 11 月 26 日 受理) 